\title{
Effect of Using Power Air Screw And Cyclone On Air - Fuel Equivalence Ratio And Monoxide Carbon Gas Emissions In Four Stroke Gasoline Engines
}

\author{
Syamsul Arifin \\ Faculty Of Engineering, Billfath University \\ Email : syamsarifin3@gmail.com
}

\begin{abstract}
The experience is observed for four strokes petrol engine for revolution $1000 \mathrm{rpm}$ $4000 \mathrm{rpm}$, with used of power air screw on carburator and cyclone on outlet intake manifold. Air - fuel mixture have passed of cyclone to combustion chamber to become turbulent flow and homogen. Then the experience of step by step used power screw and cyclone. The first investigation on standar condition, the second put of power air screw on carburator, the third put of cyclone on outlet intake manifold, the fourth put of combination of power air screw and cyclone. It was observing for increasing air - fuel equivalence ratio and reduction of exhaust $\mathrm{CO}$ concentration. Actually, used combination of power air screw and cyclone are resulted of carbon monoxide concentration drop of enough significant for $2500 \mathrm{rpm}$ and $4000 \mathrm{rpm}$, respectively $51 \%$ and $67 \%$. The carbon monoxide least concentration is $1,14 \%$ on condition $4000 \mathrm{rpm}$.
\end{abstract}

Keywords: carbon monoxide; cyclone; power air screw; reduction

\section{INTRODUCTION}

The piston combustion engine is a engine that converts heat energy into mechanical work. In the piston combustion engine, heat energy is freed by the burning of the fuel and air mixture in the combustion chamber. A homogeneous mixture of fuel and air is needed for the complete combustion process [1]. In this study, an experiment on the effect of using a power air screw (PAS) on the carburetor and cyclone on the intake manifold - outlet to the equivalent ratio of air - fuel and exhaust gas emissions [8]. In an effort to improve performance and reduce toxic exhaust gas emissions in vehicles, it can be done in various ways, one of which is by maximizing the combustion process that occurs so that the combustion is perfect. Better combustion is greatly influenced by the conditions of the air fuel mixture formed, a power air screw which functions to create a turbulent flow patterin the carburator air inlet, and a cyclone in the airfuel mixture channel that will enter the combustion chamber.

The problems studied are as follows:

-What is the comparison of the air equivalent fuel and exhaust gas composition of a gasoline motor engine in standard conditions (without PAS).

- How does the use of PAS on the carburetor effect the air-fuel equivalent ratio and the exhaust gas composition of the gasoline motor engine.

- How does the effect of using a cyclone on the intake manifold - outlet section on the air-fuel equivalent ratio and the exhaust gas composition of a gasoline motor engine.

How does the use of PAS on the carburetor and cyclone in the intake manifold - outlet

effect the comparisonair equivalent - fuel and exhaust gas composition of a gasoline motor. The carburizing process is influenced by engine speed, fuel evaporation characteristics, intake air temperature and carburetor design. High speed type modern machines, the 


\section{Tibuana}

Journal of applied Industrial Engineering-University of PGRI Adi Buana

DOI : https://doi.org/10.36456/tibuana.4.01.3178.49-54

available time to form the mixture is very limited. Therefore, high quality carburizing (with high vapor content) air velocity airflow at the point where fuel is injected must increase. Other factors that ensure high quality carburizing in a short time are the presence of volatile $\mathrm{HC}$ in the fuel. Therefore, the evaporation characteristics of the fuel indicate the need for efficient carburizing, especially at high engine speed. A machine is usually operated at different speeds and loads. For this reason, the nature of the air - fuel mixture will be supplied to the combustion chamber. Fuel and air are mixed to form three different types of mixtures, namely stoichiometric mixtures, rich mixtures and poor mixtures. A stoichiometric mixture is one mixture of sufficient air for the complete combustion of a fuel. A rich mixture is a mixture that contains less air than a stoichiometric mixture. Whereas a poor mixture is a mixture that contains more air than a stoichiometric mixture. This type of mixture can occur between rich and poor mixtures in order to continue ignition preparations. Thing this occurs in an air-fuel ratio of 19: 1 to 9:1. [5]. The actual need for the air-fuel mixture in engine operating conditions varies from ideal conditions. Engine operation is truly successful if the carburetor can produce a mixture that meets the requirements of the air-fuel ratio at idle (rich mix), cruising(low mix) and high power (rich mix). [5]. The relationship between the reactant (fuel and air) composition of the combustible mixture and the combustion product composition. This relationship depends only on conserving the mass of the respective chemical elements in the fuel and air, only a proportional composition of the fuel and air is required.

If there is enough oxygen available, the $\mathrm{HC}$ fuel can be completely oxidized. The carbon in the fuel is then converted to carbon dioxide $\mathrm{CO} 2$ and water vapor $\mathrm{H} 2 \mathrm{O}$. Consider the chemical equation for the complete combustion of 1 mole of propane $\mathrm{C}_{3} \mathrm{H}_{8}$ :

$\mathrm{C}_{3} \mathrm{H}_{8}+\mathrm{aO}_{2}=\mathrm{bCO}_{2}+\mathrm{cH}_{2} \mathrm{O}$

Obtained $b=3, c=4$ and $a=5$ then the above equation becomes:

$\mathrm{C}_{3} \mathrm{H}_{8}+5 \mathrm{O}_{2}=3 \mathrm{CO}_{2}+4 \mathrm{H}_{2} \mathrm{O}$

Air contains nitrogen, but the effect of the reaction is insignificantcombustion product is at low temperature. In general, the complete combustion of $\mathrm{HC}$ fuel is from the average

molecular composition of $\mathrm{C}_{\mathrm{a}} \mathrm{H}_{\mathrm{b}}$ with air. The overall perfect combustion equation is:

$\mathrm{C}_{\mathrm{a}} \mathrm{H}_{\mathrm{b}}+\left(\mathrm{O}_{2}+3,773 \mathrm{~N}_{2}\right)=\mathrm{aCO}_{2}+\mathrm{H}_{2} \mathrm{O}+3,773$ $(\mathrm{a}+) \mathrm{N}_{2} \ldots$ (3)

Equation (3) shows the stoichiometric (theoretical) proportions of fuel and air, that is, only enough oxygen to convert all the fuels into the complete oxidation product. Stoichiometric ratio of air - fuel or fuel - air to the fuel composition. From equation (3) it is obtained:

$$
\begin{aligned}
& \left(\frac{A}{F}\right)_{S=}\left(\frac{F}{A}\right)_{S}^{-1}= \\
& \frac{\left(1+\frac{y}{4}\right)(32+3,773 x 28,16)}{12,011+1,008 y}=\frac{34,56(4+y)}{12,011+1,008 y}
\end{aligned}
$$

The composition of the combustion product is significantly different for the fuel-poor and fuel-rich mixtures; Since the stoichiometric fuel - air ratio is dependent on the fuel composition, the ratio of actual fuel - air to fuel - stoichiometric air is more of a parameter information for the definition of a mixture composition. The fuel-air equivalent ratio is :[7] 


\section{Tibuana}

Journal of applied Industrial Engineering-University of PGRI Adi Buana

DOI : https://doi.org/10.36456/tibuana.4.01.3178.49-54

$$
=\frac{(F / A)_{a}}{(T / A)_{S t}} \ldots \ldots \ldots \ldots \ldots \ldots \ldots \ldots \ldots \ldots \ldots \ldots
$$

The inverse of is the relative ratio of air to fuel:

$\lambda=-1=\frac{[A / r]_{a}}{(A / r)_{5}}$

for poor mixture: $\quad\langle 1, \lambda\rangle 1$

for stoichiometric mixture: $\quad=\lambda=1$

for rich mixture: $>1, \lambda<1$

In order for the combustion process on a gasoline fuel motor to take place, the fuel-air mixture in the combustion room must be ignited through the spark plug electrodes to produce a spark which will then burn the entire air-fuel mixture in the combustion chamber. The process of developing the fire in the combustion chamber is divided into two stages. The initial stage is preparation for turbulent combustion. At this stage, the ignition of the spark plug electrode starts. In the early period the development of the surface area of the fire was very slow, so that the airfuel mixture burned was still small and the resulting pressure increase was relatively low, so the turbulence of the mixture flow could not affect the development of the fire (often called the laminar combustion stage). This is because the development of the flame core is only a reaction of the air-fuel mixture which is influenced by the temperature and pressure of the combustion chamber. This combustion stage lasts only about the 7.5 degree crank. rotation period. The next stage is turbulent combustion. At this stage, the core of the fire has grown bigger so that it is affected by the movement of the air-fuel mixture in the combustion chamber which moves in a turbulent combustion, as a result the core of the fire is distributed and the surface becomes wider, so that the surface area of the radiation also increases. This causes the flame propagation speed to increase and the pressure increase rapidly [9]. Factors that influence how much or at least air pollution is generated from transportation vehicles. One of the reasons is the engine design, which has the greatest influence on the air-fuel ratio. Modern transport vehicles are equipped with a catalyst converter to burn the rich air - fuel mixture (ER: $0.98+0.99$ ). This prevents the formation of NOX nitrogen oxidation emissions without producing a certain amount of $\mathrm{CO}$ carbon monoxide and volatile organics compounds VOCS. Overall, the fuel flow rate control method for obtaining a good macro mix (overall air-to-fuel ratio) and the air-fuel mixture method for obtaining the homogeneity of the micro-mixture in each cylinder are very important. The combustion chamber inducing a swirl produces a micro-mixture of fuel and air, then the $\mathrm{CO}$ and VOCS concentrations are reduced [4]. To arrive at the expected goal, the method applied has several stages: determining the object of research, preparing test equipment, making cyclone and PAS models, testing process . The research object here is intended to clarify the machine used in the research. The engine used is a gasoline motorbike, 4 stroke / Toyota, type 4K, In accordance with the research objectives, namely a comparative study between standard machines with or without PAS oncarburetor and cyclone at the intake manifold output. then direct observation is made by carrying out the test. This research was conducted at the Laboratory of the Vocational Education Development Center (VEDC)Arjosari, Malang. The test tools and machines used are the gasoline motor, 4 stroke / Toyota, type 4K, dynamometer, tachometer, fuel tube, exhaust gas analyzer, PAS and cyclone, provided that $\mathrm{A}=$ PAS position, namely the inlet of atmospheric air to the carburetor and $\mathrm{B}=$ position of the cyclone, which is the entry of the fuel and air mixture into the combustion chamber. 


\section{Tibuana}

Journal of applied Industrial Engineering-University of PGRI Adi Buana

DOI : https://doi.org/10.36456/tibuana.4.01.3178.49-54

\section{METHODOLOGY}

Before carrying out the test the important things that need to be done are:

1. Prepare machines to be tested and measuring instruments complete with their supporters.

2. Fill up the fuel sufficiently and check the cooling water on the regulator.

3. Control the oil line from the tank to the carburetor to ensure against leakage.

4. Ensuring the working conditions of the engine by starting the engine and preheating it, and preparing observation sheets.

In this research, the engine is turned on with the gas trotle fully open, then the braking load is given to get the engine speed that varies as desired. While the steps taken by researchers in order to collect test data are:

1. Starting the engine according to the need, so that the engine is stationary

2. Preheat 5 minutes at idle, to ensure engine working conditions and to reach engine working temperature

3. To start data collection, first the gas throtle is opened slowly until it is fully open, then the load is given to itachieved the desired engine speed.

4. Shut down the engine when the test has been completed.

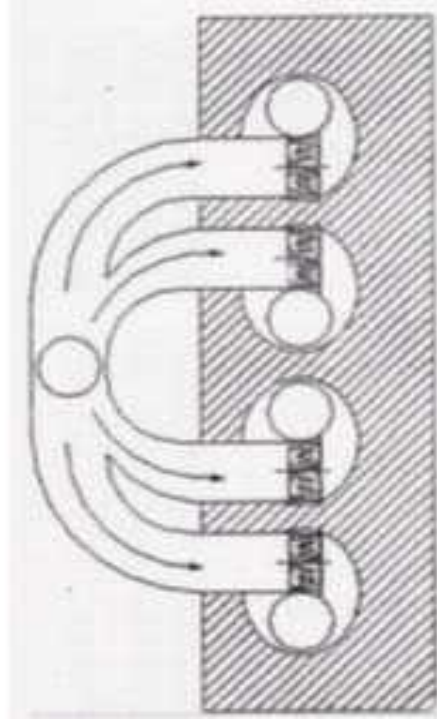

Figure 1: Intake Manifold

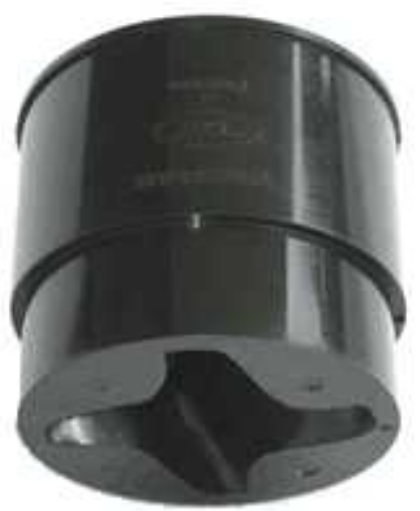

Figure 2: PAS Model

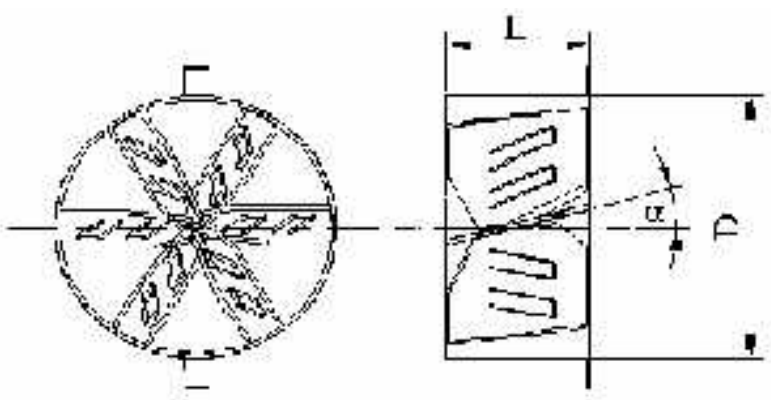

Figure 3: Cyclone Model 
Tibuana

Journal of applied Industrial Engineering-University of PGRI Adi Buana

DOI : https://doi.org/10.36456/tibuana.4.01.3178.49-54

p-ISSN 2622-2027

$e$-ISSN 2622-2035

\section{RESULTS AND DISCUSSION}

Table 1. Engine speed, (A / F) equivalent or $\lambda$ and concentration of $\mathrm{CO}$

\begin{tabular}{llllllllll}
\hline Cycle & \multicolumn{2}{l}{ Condition } & & & & & & \\
$(\mathrm{rpm})$ & \multicolumn{2}{l}{ Standart } & PAS & & \multicolumn{2}{c}{ Cyclon } & \multicolumn{2}{c}{ PAS+ Cyclon } \\
& $\lambda$ & CO,\% & $\lambda$ & CO,\% & $\lambda$ & CO,\% & $\lambda$ & CO, $\%$ \\
& & & & & & & & \\
\hline 1000 & 1.4 & 0.41 & 1.39 & 1.41 & 1.24 & 1.29 & 1.234 & 1.31 \\
1500 & 1.3 & 1.89 & 1.228 & 2.29 & 1.229 & 2.09 & 1.377 & 1.06 \\
2000 & 1.29 & 2.4 & 1.036 & 2.80 & 1.058 & 2.9 & 0.99 & 1.7 \\
2500 & 0.926 & 5.65 & 0.926 & 3.27 & 0.998 & 3.01 & 0.95 & 2.77 \\
3000 & 0.860 & 5.73 & 0.910 & 3.33 & 0.959 & 2.81 & 0.922 & 2.38 \\
3500 & 0.841 & 4.39 & 0.953 & 3.09 & 0.986 & 2.69 & 0.958 & 2.06 \\
4000 & 0.901 & 3.47 & 0.959 & 2.17 & 0.959 & 1.74 & 0.969 & 1.14 \\
\hline
\end{tabular}

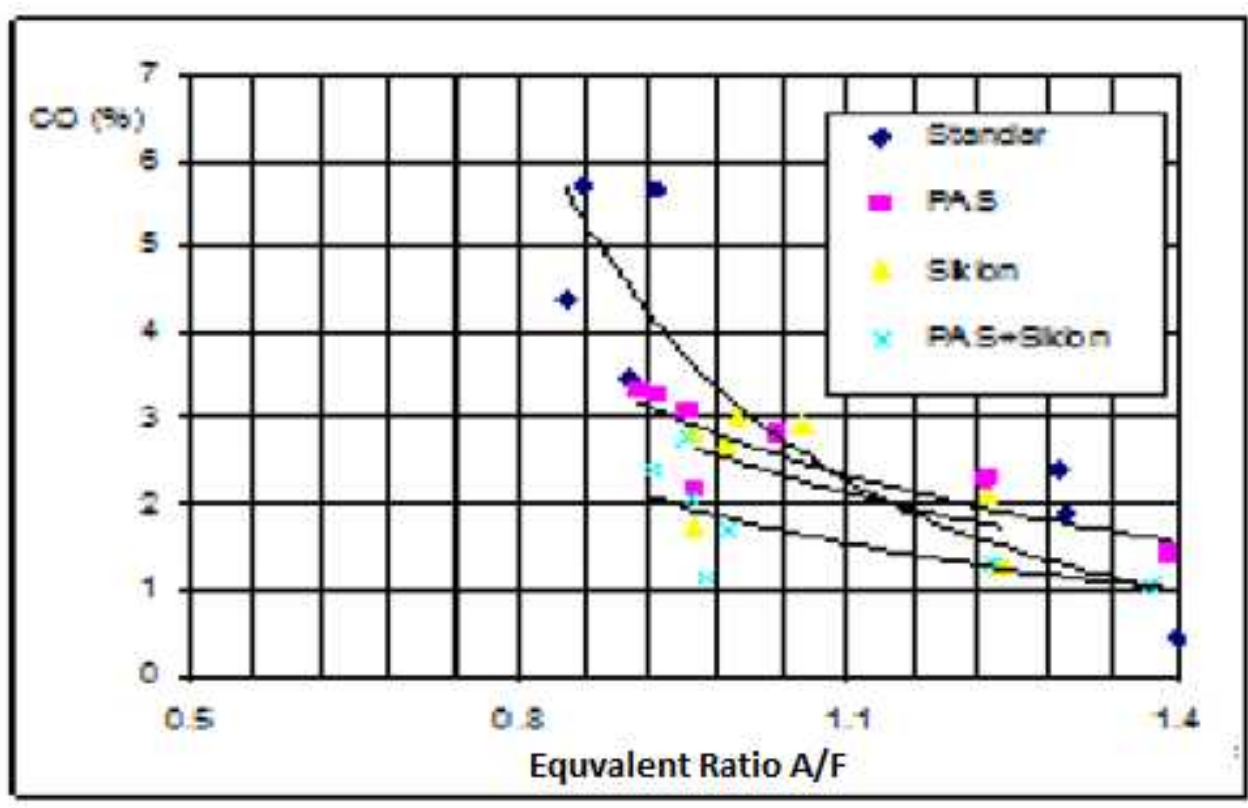

Figure 4. Effect Relationship of CO Concentrations

Figure 4 shows the relationship between the concentration of carbon monoxide $(\mathrm{CO})$ and the air-fuel equivalent ratio (A / F) of a four-stroke vehicle with variations in engine speed $1000,1500,2000,2500,3000,3500,4000 \mathrm{rpm}$. This experiment was carried out in standard conditions and the addition of a PAS device to the carburetor and a cyclone on the intake manifold outlet. 


\section{Tibuana}

Journal of applied Industrial Engineering-University of PGRI Adi Buana

DOI : https://doi.org/10.36456/tibuana.4.01.3178.49-54

From the test results, the lowest $\mathrm{CO}$ concentration was $\approx 0.41 \%$ with the air-fuel equivalent ratio $\approx 1.4$ (1000 rpm rotation), this is said to be the richest mixture compared to other conditions. While the largest concentration was $\approx$ $5.73 \%$ with an equivalent ratio of air - fuel $\approx 0.86$ (3000 $\mathrm{rpm}$ rotation) and it was said to be a poor mixture. These results were obtained from testing under standard conditions, meaning a carburetor without a PAS and intake manifold - outlet Without a cyclone.The $\mathrm{CO}$ concentration increases in the rich mixture in the exhaust gas steadily as the air-fuel equivalent ratio increases as more fuel increases. Conversely, the $\mathrm{CO}$ concentration is reduced in the poor mixture.

\section{REFERENCES}

1. Aris Munandar, W, 1994, Penggerak Mula Motor Bakar Torak,Bandung: Penerbit ITB.

2. Arifin, S., 2003, Pengaruh Perbedaan Penempatan Siklon pada Intake Manifold dan Saluran Udara dengan Kondisi Standar pada Motor Bensin terhadap Unjuk Kerja dan Emisi Gas Buang, Malang : Universitas Brawijaya - Malang, 11 Oktober , hal. 106 s.d. 109.

3. Arifin, S., 2003, Pengaruh Penggunaan Siklon pada Intake Manifold Motor Bensin terhadap UnjukKerjadanEmisi Gas Buang, Yogyakarta :Institut Sains danTeknologi AKPRIND Yogyakarta, 18 Oktober, hal. 188 s.d. 192.

4. Cooper, C.D., and Alley, F.C., 1994, Air Pollution Control, USA : Waveland Press, Inc.

5. Ganesan, V., 1995, Internal Combustion Engines, New Delhi : McGraw-Hill Publishing Company.

\section{CONCLUSIONS}

From the test results, it can be seen that the installation of PAS on the carburetor and cyclone on the intake manifold - outlet can reduce the $\mathrm{CO}$ concentration with the same engine speed - quite significantly, compared to standard conditions. This is evidenced by the decrease in concentration at the rotation of $2500 \mathrm{rpm}$ and $4000 \mathrm{rpm}$, reaching $51 \%$ and $67 \%$, respectively. The lowest $\mathrm{CO}$ concentration $\approx 1.14 \%$ occurred in operating conditions with a rotation of 4000 rpm.

6. Heisler, Heinz., 1995, Advanced Engine Technology, London : The College of North West London Willesden Centre.

7. Heywood, J.B., 1988, Internal Combustion Engine Fundamentals,Singapore : McGrawHill Book Company.

8. Rusman, A., 2003, Pengaruh Penggunaan Power Air Screw dan FiltechTerhadapUnjuk Kerja Serta Emisi Gas Buang pada Motor Bensin Toyota Kijang 4K 1300 CC , Skripsi tidak diterbitkan , Surabaya, Fakultas Teknik ITATS.

9. Supriyadi, A., 2003, Pengaruh Penggunaan Turbo Siklon pada Saringan Udara dan Siklonpada Intake Manifold Motor Bensin Toyota Kijang 4K Terhadap Unjuk Kerja dan EmisiGas M. Young, The Techincal Writers Handbook. Mill Valley, CA: University Science, 1989.

10. Waluyo, D. A., Pramana, Y. B. (2019). DESIGN "SANGRAI" TOOL FOR COFFE WITH STIRER FIN. Tibuana, 5-9. 